\title{
Harnessing Technical and Vocational Education and Training and Entrepreneurship Education to Address Unemployment in Lusaka Province, Zambia
}

\author{
Phillip Mubanga', Oo Yu Hock ${ }^{2,3}$, Asif Mahbub Karim4, Zulkifli Senteri5, \\ Innocent Mutale Mulenga ${ }^{6}$, Miriam Preckler ${ }^{7}$
}

${ }^{1}$ Directorate of Finance and Administration, Technical Education Vocational and Entrepreneurship Training Authority (TEVETA), Lusaka, Zambia

${ }^{2}$ Asia e University, Kuala Lumpur, Malaysia

${ }^{3}$ Binary University of Management and Entrepreneurship, Puchong, Malaysia

${ }^{4}$ Office of the Dean, Binary Graduate School (BGS), Binary University of Management and Entrepreneurship, Puchong, Malaysia ${ }^{5}$ Office of the Deputy Vice Chancellor, Binary University of Management and Entrepreneurship, Puchong, Malaysia ${ }^{6}$ School of Education, Curriculum Studies and Teacher Teaching, The University of Zambia (UNZA), Lusaka, Zambia ${ }^{7}$ Organization of Ibero-American States, Asuncion, Paraguay

Email:pmubanga@yahoo.co.uk

How to cite this paper: Mubanga, P., Hock, O.Y., Karim, A.M., Senteri, Z., Mulenga, I.M. and Preckler, M. (2019) Harnessing Technical and Vocational Education and Training and Entrepreneurship Education to Address Unemployment in Lusaka Province, Zambia. Open Journal of Social Sciences, 7, 153-179.

https://doi.org/10.4236/jss.2019.75013

Received: April 3, 2019

Accepted: May 17, 2019

Published: May 20, 2019

Copyright ( 2019 by author(s) and Scientific Research Publishing Inc. This work is licensed under the Creative Commons Attribution International License (CC BY 4.0)

http://creativecommons.org/licenses/by/4.0/ (c) (i) Open Access

\begin{abstract}
The aim of this study was to highlight how a combination of TVET and entrepreneurship education can be harnessed to address the problem of unemployment as well as underutilisation of human resources, in Lusaka Province, Zambia, to foster sustainable social economic development. A questionnaire was administered to TVET students. A representative sample of 480 respondents was targeted. Interview respondents included TVET instructors, TVET administrators, TVET government officers, Industry experts and parents of TVET learners. The sample was proportionately shared among the eight districts in Lusaka province. The study was conducted from April 2018 to March 2019. This was a mixed methods research. Quantitative data was analysed using Statistical Package for Social Sciences (SPSS) and qualitative data through thematic approach. The findings indicated that unemployment as well as underutilisation of human resources can be addressed by tapping into the entrepreneurial ambitions of TVET Learners; encouraging, enticing and appealing to students by asking them to consider entrepreneurship as a vocation or career pathway; offering entrepreneurship education to TVET learners; sensitisation and robust rollout of TVET and entrepreneurship education national wide through policy directives; and, developing appropriate curriculum to support the awareness and recognition that TVET learners that acquire entrepreneur-
\end{abstract}


ship knowledge and skills are potential productive human resource for different industry sectors to drive sustainable economic development.

\section{Keywords}

Technical Education, Vocational Training, Entrepreneurship, Harnessing, Underutilisation, Economic Development

\section{Introduction}

The reason for conducting this research was to suggest some solutions that can contribute towards resolving the problem of high unemployment prevailing in Lusaka province, Zambia emanating from underdevelopment. According to CSO (2018) [1], unemployment stood 7.79\%, and youth unemployment at $16.3 \%$, by any standards these rates are high. The unemployment has been cited as one of the main causes of poverty standing at $60 \%$ (CSO, 2015) [2]. This is consistent with the findings that in spite of the abundant natural resources endowment and a young population with an average age of 17 years, Zambia has remained less industrialised, underdeveloped and with most of its population on average living in abject poverty (World Bank, 2018) [3]. Therefore, the aim was to highlight and suggest how a combination of TVET and entrepreneurship education can be harnessed as some of the ways that can be embraced in addressing the problem of unemployment as well as underutilisation of human resources in Lusaka province, Zambia in order to bring about social economic development. It is expected that when unemployment is reduced, poverty levels can plummet.

\subsection{Background}

Lusaka province is one of the ten provinces in Zambia. Zambia is a country situated in Southern Africa with a total land area of $752,618 \mathrm{~km}^{2}$. It is surrounded by eight neighbouring countries namely: Angola, Botswana, DR Congo, Malawi, Mozambique Namibia, Tanzania and Zimbabwe. The average population of Zambia is currently estimated at 17.2 million (Trading Economics, 2019) [4]. According to the latest census, Zambia's population in 2010 was $13,092,666$. Comparing to other provinces in Zambia, Lusaka Province had the largest population at 2,191,225 followed by Copperbelt Province with 1,972,317. Muchinga Province had the smallest population at 711,657 . The country is sparsely populated with a density of 17.4 persons. Lusaka Province was the most densely populated province with 100.1 persons per square kilometre while North Western Province was the least densely populated province with 5.8 persons per square kilometre (CSO, 2012) [5]. Lusaka province which is the focus of this study has eight districts.

\subsection{Problem Statement}

The study had five research questions. This article will look at research question 
one which had four key variables with several underlying rudimentary factors. In a series of articles, of which this is the first, the article focuses on one key variable, and the other three will be covered in subsequent articles. The question revolved around evaluating, the degree to which a combination of TVET and entrepreneurship education, played a role in addressing the problem of unemployment, as well as, underutilisation of human resources partly caused by underdevelopment in order to foster sustainable economic development. There is prevalent acute unemployment, as well as, underutilisation of human capital in Lusaka province, Zambia. The question sought to provide means and ways that can be explored to resolve the endemic unemployment, with a view of improving the living standards of many citizens. There are a number of ways of tackling this problem as supported by many research done in other parts of the globe, persuading TVET learners to take up entrepreneurship. There is influence of personality traits and persuasive messages on entrepreneurial intentions of learners (Pillis et al., 2007) [6]. Encouraging TVET for employment and sustainable economic development through career development programmes (Rayan, 2015) [7]. TVET graduates and dropouts can create technology based enterprises (Grundstén, 2004) [8]. Entrepreneurial motivation and determinant factors of the TVET graduate to become entrepreneurs (Kidane \& Raju, 2016) [9]. Female entrepreneurs contribute to reducing unemployment (Holland-Noronha, 2010) [10]. Start-ups in technical or manufacturing industry by TVET graduates can mitigate underutilisation of human resource (Suradi et al., 2017) [11]. TVET is an important factor in a country's economic development (Pavlova, 2014) [12]. In Zambia, Hoppers (1984) [13] researched on youth, non-formal vocational training and employment and ignored entrepreneurship. Mwiya (2014) [14] conducted a research on the impact of entrepreneurship education among university students and not TVET students. Adequate provision of funds for entrepreneurship programmes, proper evaluation of entrepreneurship education schemes and entrepreneurship competences such as management skills were required for self-employment (Garba, G. A. et al., 2017) [15]. TVET and entrepreneurship presents opportunity for citizens to create their own wealth and shows the importance of entrepreneurship programme in TVET as a ways of making youths to be self-reliant, capable of solving unemployment problems and contribute to economic growth and development of their countries (Ogbaekirigwe \& Ugochukwu, 2017) [16]. Participation in TVET enables learners (especially women and female youths) to find gainful self-employment in aquaculture technical, vocational, and entrepreneurship (World Fish, 2018) [17]. There is great potential in enhancing the entrepreneurial mindset of learners in TVET institutions in order to create many job creators (Dahalan, D. et al., 2018) [18]. Many TVET institutions have emphasized engagement in self-employment as a solution to the employability criteria in determining the quality of TVET graduates (Ismail et al., 2019) [19]. This article highlights how the combination of TVET and entrepreneurship education can be used to address the problem of unemployment, as well as, underutilisa- 
tion of human resources to drive social economic development in Lusaka province, Zambia.

\subsection{Theoretical Framework}

The theoretical basis for this study was based on concepts and theories of TVET and entrepreneurship education. The theoretical framework for this study was premised on the variables on which the selected theories for this research are anchored. The following are the concepts and theories. The Concept of TVET: According to UNESCO (2015) [20], TVET deals with the acquisition of knowledge and skills for the world of work. In different parts of the world, TVET may be referred to using different names, such as apprenticeship training, workforce education, and vocational education to mention but a few, but the content and objectives still remain the same. In the context of this research, TVET graduates should be able to set up technical and vocational related business without necessary having to look for paid employment. Entrepreneurship Intentions Model: Bird (1988) [21] model of entrepreneurial intentionality is founded on the cognitive theory that tries to predict human behavior. The rationale of this model is premised on the reasoning that, based on the beliefs of an individual, attitudes are formed which are then translated into certain behaviour. In this case for this study the behaviour of TVET students should culminate in them having intentions to start a business. Human capital theory: Lener et al. (1997) [22], the human capital theory indicates that the performance of a business to a larger extent is influenced by a person's level of education, field of education, past entrepreneurial experience, business experience and business skills possessed. This theory advocates that human capital is a critical resource that makes organisations achieve results through work performance. That is why it is important for entrepreneurs and would-entrepreneurs to understand that they need to work hard if their businesses are to succeed. Entrepreneurship Education theory: According to Kuratko (2005) [23] entrepreneurship education is an important influence among students' entrepreneurial intentions in learning institutions. Entrepreneurship curricula are one of the predictors in providing a good training model for entrepreneurship education. Research on academic entrepreneurship states that, through teaching methods and training, learners will develop entrepreneurial intentions. In this case TVET students should aspire to start business in their areas of competence using TVET occupational knowledge and skills.

\section{Methods}

The study was conducted during the period April 2018 to March 2019 in all the eight districts of Lusaka province in the selected technical and vocational training institutions. The eight districts in Lusaka province were Chilanga, Chirundu, Chongwe, Kafue, Luangwa, Lusaka, Rufunsa and Shibuyungi. This was a mixed methods research which adopted both quantitative and qualitative approaches. 
For the quantitative part of this study, the sample was selected from the population of 17,981 students using stratified random sampling under probability sampling. Stratified random sampling was used to select learners from one hundred and ten TVET institutions in Lusaka province. The stratification variable in this case was the district. The 110 TVET institutions were grouped according to the eight districts in which they are located in the province, and this was the criteria used to divide the sampling frame into eight discrete strata. The samples were then selected systematically from the districts strata. The technique entailed selecting learners at an established regular interval in a systematic manner using the sampling fraction until the entire sample was exhausted. The stratification using the districts as sampling variable was ideal as it facilitated and ensured correct representation of the learners from institutions in the districts within the sample. The administrators' questionnaire was administered in the same selected vocational schools. The qualitative samples were drawn through non-probability sampling methods using purposive sampling and snowball sampling. The qualitative sample for TVET instructors, administrators and government officials and Industry experts were selected by using purposive sampling to collect data. Purposive sampling was used because this method allows the researcher to select respondents who provide the richest information for in-depth analysis related to the central issues being studied (Kombo \& Tromp, 2006) [24]. While snowball sampling was adopted to come up with the sample that was used to collect data from parents of TVET learners.

\subsection{Target Population, Sample Size and Demographics}

The target population for this study was all TVET learners, TVET administrators, TVET Instructors, TVET government officers, Industry experts and parents of TVET learners in Lusaka province, Zambia. The sample consisted of 392 TVET learners, 24 TVET instructors, 16 TVET administrators, 16 TVET government officers, 16 Industry and 16 parents. The criteria for inclusion of respondents for the TVET learners was those in the final year of study; for the rest of the respondent groups with the exception of TVET parents (snowball sampling) the samples were selected purposively. Tables 1-5 display the demographics of the respondents.

The distribution of TVET learners by gender is depicted in Table 1. The percentages in the table indicated that the male and female learners were fairly represented in the study. There was a gender disparity of $5.6 \%$.

Table 2, displays the gender, frequency and percentage distribution of TVET

Table 1. Frequency and percentage distributions by gender of TVET Learners.

\begin{tabular}{ccccc}
\hline & Frequency & Percent & Valid Percent & Cumulative Percent \\
\hline Male & 207 & 52.8 & 52.8 & 52.8 \\
Female & 185 & 47.2 & 47.2 & 100.0 \\
Total & 392 & 100.0 & 100.0 & \\
\hline
\end{tabular}


Table 2. Frequency and percentage distribution by gender of TVET administrators.

\begin{tabular}{ccccc}
\hline & Frequency & Percent & Valid Percent & Cumulative Percent \\
\hline Male & 11 & 68.8 & 68.8 & 68.8 \\
Female & 5 & 31.3 & 31.3 & 100.0 \\
Total & 16 & 100.0 & 100.0 & \\
\hline
\end{tabular}

Table 3. Frequency and percentage distribution by gender of interview respondents.

\begin{tabular}{ccccc}
\hline & Frequency & Percent & Valid Percent & Cumulative Percent \\
\hline Male & 50 & 76.0 & 76.0 & 76.0 \\
Female & 16 & 24.0 & 24.0 & 100.0 \\
Total & 66 & 100.0 & 100.0 & \\
\hline
\end{tabular}

Table 4. Frequency and percentage distribution by type of interview respondent.

\begin{tabular}{ccccc}
\hline & Frequency & Percent & $\begin{array}{c}\text { Valid } \\
\text { Percent }\end{array}$ & $\begin{array}{c}\text { Cumulative } \\
\text { Percent }\end{array}$ \\
\hline TVET Administrators & 18 & 27.2 & 27.2 & 27.2 \\
TVET Instructors & 17 & 25.8 & 25.8 & 53.0 \\
TVET Government Officials & 9 & 13.6 & 13.6 & 66.6 \\
Parents of TVET Learners & 11 & 16.7 & 16.7 & 83.3 \\
Industry Experts & 11 & 16.7 & 16.7 & 100.0 \\
Total & 66 & 100.0 & 100.0 & \\
\hline
\end{tabular}

Abbreviations: TVET-Technical and Vocational Education and Training; TEVETA-Technical Education Vocational and Entrepreneurship Training Authority.

Table 5. Summary of mean and standard deviation for TVET learners' responses.

$\begin{array}{cc}\text { N Valid } & 392 \\ \text { Missing } & 0 \\ \text { Mean } & 5.72 \\ \text { Std. Error Mean } & 0.049 \\ \text { Std. Deviation } & 0.963 \\ \text { Sum } & 2243\end{array}$

administrators who completed the questionnaire for vocational institution administrators. The distribution was $68.8 \%$ male and the remainder $31.3 \%$ female. It was noted that there was a larger proportion of male administrators in the TVET institutions compared to female administrators.

Table 2 shows a total of 66 respondents that participated in the semi-structured interview. A proportion of $76 \%$ were male and $24 \%$ female. Table 4 shows the different types of respondents that took part in the interview. These are grouped into five categories. These respondents are individuals with immense experience in vocational training and related occupations who were purposely selected to provide vital information for this study. These included vocational training pro- 
vider administrators, Instructors, government officials, parents or guardians and Industry experts.

\subsection{Experimental Protocol}

The research question aimed to evaluate the degree to which a combination of TVET and entrepreneurship education played a role in addressing unemployment, as well as, underutilisation of human resources in order to drive sustainable economic development in Lusaka province. Three groups of respondents namely; TVET learners, TVET administrators and Industry experts were considered key in providing response to this question. In the first instance, there was need to gauge the entrepreneurial ambitions of learners, followed by offering entrepreneurship education, at the time when students were pursuing vocational training, and finally the consideration of TVET learners as potential productive human resources when they leave or graduate. The learners were assessed to evaluate what they can become, either as valuable employees or employers in terms of the possibility of them becoming entrepreneurs. In order to obtain in-depth comprehension of the data derived from the questionnaire, descriptive statistical analysis was performed to compare the frequencies, totals, means and standard deviations of the responses of the learners from the various districts. The survey questions are shown in Appendix 1 (extract of section A from the full questionnaire). The assessment of entrepreneurial ambitions of TVET learners during their tenure at vocational schools entailed adoption of quantitative and qualitative approaches (Creswell, 2003) [25]. This study also adopted the pragmatism paradigm (Tashakkori \& Teddlie, 1998) [26] with the ontological perspective that is both independent and internal giving a multiple view chosen to best enable answering of the research questions. The epistemological aspects are that either or both observable phenomena and subjective meanings can provide acceptable knowledge dependent upon the research questions dealing with chronic unemployment, as well as, underutilisation of human resources. This approach enabled the researchers to focus on practical applied research, by integrating the different perspectives to help interpret the data. The pragmatism paradigm dictated that the researchers had to exercise professional values when conducting this study. Values undoubtedly, played a large role in interpreting the results. Therefore, the researchers in this study adopted both the objective and subjective points of view. The pragmatism paradigm also entailed adoption of the mixed methods research approach embracing both the quantitative and qualitative techniques for data collection. Both qualitative and quantitative data was collected for this study.

The questionnaires and semi-structured interviews were utilised as research instruments to gather data. The learners' questionnaire comprised four sections, due to the bulkiness of the study, this article concentrated on section A of the learners' questionnaire. Section A consisted of eight closed items that sought to elicit information on "entrepreneurial ambitions of TVET learners". The closed 
questions enabled researchers to obtain objective responses. The questionnaire was self-administered to all 392 learners surveyed in the technical and vocational training schools. The learners were given sufficient time to independently respond to the questionnaire items in a relaxed environment. The TVET administrators and Industry experts that were interviewed were purposely selected and these responded to questions on the interview guide.

\subsection{Variables Studied}

The variables included entrepreneurial ambitions; entrepreneurship education; technical and vocational education and training; and TVET learners as potential productive human resource.

\subsection{Statistical Analysis}

Quantitative data was analysed using the Statistical Package for Social Sciences (SPSS) Version 23, to perform descriptive and inferential statistics, in terms of frequencies and distributions. In this study, the statistical tests that were conducted included; one sample t-test and single factor analysis of variance (One-way ANOVA). Data collected from interviews of TVET instructors, TVET administrators, TVET government officers, Industry experts and parents of TVET learners was analysed using thematic approach. The themes that this study focused on included: how early were the instructors able to identify learners' interest to venture into entrepreneurship? The type of teaching practices and instructors' behaviour that may discourage learners from starting enterprises. The other themes were: acceptability of TVET careers as a source of successful and sustainable livelihood. The focus was also on cultural themes and how culture played a part on the learners' intentions to start an enterprise.

\section{Results}

Table 5 shows the overall picture of the responses obtained from learners in all the districts of Lusaka with the exception of Shibuyunji district which at the time of data collection for this study had no vocational training institution, neither was there any school that was offering vocational training under the Secondary School Vocational Education and Training (SSVET) pathway. A total number (n) of 392 learners responded to the questionnaire which was self-administered by the researchers in the training institutions. A total of 2243 responses were recorded for the eight questions in Part A of the questionnaire, giving a mean of 5.72 and a standard deviation $(S D)$ of 0.963 .

Table 6 shows the distribution of the respondents in the districts of Lusaka province in proportion to the student population as obtained from the Learner Data Management System (LDMS) of the Zambian TVET Authority, namely; the Technical Education Vocational and Entrepreneurship Training Authority (TEVETA). The frequency of responses from learners in the districts, in percentage terms, were $1.3 \%$ for Chilanga and Chirundu, 3.8\% for Chongwe, $2.0 \%$ 
Table 6. Frequency and percentage distribution of TVET learners in Lusaka province.

\begin{tabular}{ccccc}
\hline District & Frequency & Percent & $\begin{array}{c}\text { Valid } \\
\text { Percent }\end{array}$ & $\begin{array}{c}\text { Cumulative } \\
\text { Percent }\end{array}$ \\
\hline Chilanga & 5 & 1.3 & 1.3 & 1.3 \\
Chirundu & 5 & 1.3 & 1.3 & 2.6 \\
Chongwe & 15 & 3.8 & 3.8 & 6.4 \\
Kafue & 8 & 2.0 & 2.0 & 8.4 \\
Luangwa & 5 & 1.3 & 1.3 & 9.7 \\
Lusaka & 349 & 89.0 & 89.0 & 98.7 \\
Rufunsa & 5 & 1.3 & 1.3 & 100.0 \\
Shibuyunji & 0 & 0 & 0 & 100.0 \\
Total & 392 & 100.0 & 100.0 & \\
\hline
\end{tabular}

for Kafue, $1.3 \%$ for Luangwa, $89.0 \%$ for Lusaka and 1.3\% for Rufunsa.

\subsection{Entrepreneurial Ambitions of TVET Learners}

Part A of the questions on the questionnaire evaluated the entrepreneurial ambitions of learners in vocational institutions. Eight questions were posed and the learners were required to answer using a five point Likert scale $(5=$ Strongly Agree, $4=$ Agree, 3 = Neutral, $2=$ Disagree and $1=$ Strongly Disagree). The results for responses to each question are shown in the Tables 7-15.

\subsubsection{Mean, Standard Deviation and T-Tests for Entrepreneurial Ambitions Variable}

Table 7 displays the mean and standard deviation for the entrepreneurial ambitions variable.

Analysis of the entrepreneurship ambitions variable using the five point Likert scale for the eight questions in Part A of the questionnaire from (a) to (h) shows that the mean score ranged from 4.58 to 2.85 . Hard work and sacrifice (e) had the highest mean of 4.58 , followed by (b) entrepreneurial aspiration (personality, attitude and ambition) at 4.24. Questions (d), (a), and (g) had means above 4.00 and the standard deviation ranged from 0.725 to 1.282 . Generally, the responses were in the affirmative. Tables 7-15 show the detailed responses for each question.

A total of $82.4 \%$ of the learners in Table 8 indicated that they had intentions of starting a business after graduation, $17.6 \%$ had not made up their mind, while $7.7 \%$ had no intention at all of starting a business.

Table 9 shows many learners at $89.8 \%$ were of the view that the entrepreneurial aspiration depended on the factors of personality, attitude and ambition. $10.2 \%$ were not sure and $6.6 \%$ held a contrary view.

As reflected in Table 10, a total of $44.1 \%$ learners indicated that it was not their cultural norm to own a business, $20.9 \%$ were not sure and only $25 \%$ confirmed that it was a norm in their culture to own a business. 
Table 7. Mean and standard deviation for entrepreneurial ambitions variable.

\begin{tabular}{|c|c|c|c|c|}
\hline & $\mathrm{N}$ & Mean & $\begin{array}{c}\text { Std. } \\
\text { Deviation }\end{array}$ & Std. Error \\
\hline a. Intention to start a business upon graduation. & 392 & 4.20 & 0.932 & 0.047 \\
\hline $\begin{array}{l}\text { b. Entrepreneurial aspiration depends on } \\
\text { personality, attitude and ambition. }\end{array}$ & 392 & 4.24 & 0.832 & 0.042 \\
\hline c. Cultural norm to own a business. & 392 & 2.85 & 1.282 & 0.065 \\
\hline $\begin{array}{l}\text { d. At one point in life had considered starting a } \\
\text { business. }\end{array}$ & 392 & 4.21 & 0.893 & 0.045 \\
\hline $\begin{array}{l}\text { e. Hard work and sacrifice important to succeed } \\
\text { as an entrepreneur. }\end{array}$ & 392 & 4.58 & 0.725 & 0.037 \\
\hline $\begin{array}{l}\text { f. Strong passion and desire to become } \\
\text { an entrepreneur. }\end{array}$ & 392 & 3.94 & 1.020 & 0.052 \\
\hline $\begin{array}{l}\text { g. Entrepreneurship a better path to personal } \\
\text { achievement and success. }\end{array}$ & 392 & 4.18 & 0.868 & 0.044 \\
\hline $\begin{array}{l}\text { h. Many family members are successful } \\
\text { business owners. }\end{array}$ & 392 & 3.15 & 1.196 & 0.060 \\
\hline
\end{tabular}

Table 8. Frequency and percentage distribution of learners' responses on whether they intend to start a business when they graduate.

\begin{tabular}{ccccc}
\hline & Frequency & Percent & Valid Percent & $\begin{array}{c}\text { Cumulative } \\
\text { Percent }\end{array}$ \\
\hline Strongly Disagree & 10 & 2.6 & 2.6 & 2.6 \\
Disagree & 10 & 2.6 & 2.6 & 5.1 \\
Neutral & 49 & 12.5 & 12.5 & 17.6 \\
Agree & 147 & 37.5 & 37.5 & 55.1 \\
Strongly Agree & 176 & 44.9 & 44.9 & 100.0 \\
Total & 392 & 100.0 & 100.0 & \\
\hline
\end{tabular}

Table 9. Frequency and percentage distribution of learners' responses on whether the aspiration to become an entrepreneur depends on personality, attitude and ambition.

\begin{tabular}{ccccc}
\hline & Frequency & Percent & Valid Percent & $\begin{array}{c}\text { Cumulative } \\
\text { Percent }\end{array}$ \\
\hline Strongly Disagree & 8 & 2.0 & 2.0 & 2.0 \\
Disagree & 10 & 2.6 & 2.6 & 4.6 \\
Neutral & 22 & 5.6 & 5.6 & 10.2 \\
Agree & 193 & 49.2 & 49.2 & 59.4 \\
Strongly Agree & 159 & 40.6 & 40.6 & 100.0 \\
Total & 392 & 100.0 & 100.0 & \\
\hline
\end{tabular}

Table 11 shows that $7.4 \%$ of learners have never thought of starting a business in their life. A total of $88 \%$ indicated of having thought of starting an enterprise, while $4.6 \%$ were of a neutral position. 
Table 10. Frequency and percentage distribution of learners' responses on whether in their culture owning a business was the norm.

\begin{tabular}{ccccc}
\hline & Frequency & Percent & Valid Percent & $\begin{array}{c}\text { Cumulative } \\
\text { Percent }\end{array}$ \\
\hline Strongly Disagree & 69 & 17.6 & 17.6 & 17.6 \\
Disagree & 104 & 26.5 & 26.5 & 44.1 \\
Neutral & 82 & 20.9 & 20.9 & 65.1 \\
Agree & 92 & 23.5 & 23.5 & 88.5 \\
Strongly Agree & 45 & 11.5 & 11.5 & 100.0 \\
Total & 392 & 100.0 & 100.0 & \\
\hline
\end{tabular}

Table 11. Frequency and percentage distribution of learners' responses on whether at one point in their life had considered starting a business.

\begin{tabular}{ccccc}
\hline & Frequency & Percent & Valid Percent & $\begin{array}{c}\text { Cumulative } \\
\text { Percent }\end{array}$ \\
\hline Strongly Disagree & 6 & 1.5 & 1.5 & 1.5 \\
Disagree & 23 & 5.9 & 5.9 & 7.4 \\
Neutral & 18 & 4.6 & 4.6 & 12.0 \\
Agree & 179 & 45.7 & 45.7 & 57.7 \\
Strongly Agree & 166 & 42.3 & 42.3 & 100.0 \\
Total & 392 & 100.0 & 100.0 & \\
\hline
\end{tabular}

Table 12. Frequency and percentage distribution of learners' responses on whether they believed hard work and sacrifice were important in order to succeed as an entrepreneur.

\begin{tabular}{ccccc}
\hline & Frequency & Percent & Valid Percent & $\begin{array}{c}\text { Cumulative } \\
\text { Percent }\end{array}$ \\
\hline Strongly Disagree & 3 & 0.8 & 0.8 & 0.8 \\
Disagree & 8 & 2.0 & 2.0 & 2.8 \\
Neutral & 13 & 3.3 & 3.3 & 6.1 \\
Agree & 103 & 26.3 & 26.3 & 32.4 \\
Strongly Agree & 265 & 67.6 & 67.6 & 100.0 \\
Total & 392 & 100.0 & 100.0 & \\
\hline
\end{tabular}

Overwhelming 93.9\% of learners in Table 12, affirmed that hard work and personal sacrifice were vital attributes for one to be a successful entrepreneur. The disapproval responses stood at $2.8 \%$ and $3.3 \%$ were unsure.

In Table 13, 74.5\% of the learners expressed passion to become an entrepreneur, $9.4 \%$ were not prepared to strive to be an entrepreneur and $16.1 \%$ were in the middle of the road.

A total of $83.5 \%$ learners as depicted in Table 14 indicated that becoming an entrepreneur was a better route to personal achievement and success as opposed 
Table 13. Frequency and percentage distribution of learners' responses on whether they can do whatever it takes to become an entrepreneur.

\begin{tabular}{ccccc}
\hline & Frequency & Percent & Valid Percent & $\begin{array}{c}\text { Cumulative } \\
\text { Percent }\end{array}$ \\
\hline Strongly Disagree & 14 & 3.6 & 3.6 & 3.6 \\
Disagree & 23 & 5.9 & 5.9 & 9.4 \\
Neutral & 63 & 16.1 & 16.1 & 25.5 \\
Agree & 165 & 42.1 & 42.1 & 67.6 \\
Strongly Agree & 127 & 32.4 & 32.4 & 100.0 \\
Total & 392 & 100.0 & 100.0 & \\
\hline
\end{tabular}

Table 14. Frequency and percentage distribution of learners' responses on whether they believe becoming an entrepreneur was a better path to personal achievement and success.

\begin{tabular}{ccccc}
\hline & Frequency & Percent & Valid Percent & $\begin{array}{c}\text { Cumulative } \\
\text { Percent }\end{array}$ \\
\hline Strongly Disagree & 4 & 1.0 & 1.0 & 1.0 \\
Disagree & 17 & 4.3 & 4.3 & 5.4 \\
Neutral & 44 & 11.2 & 11.2 & 16.6 \\
Agree & 168 & 42.9 & 42.9 & 59.4 \\
Strongly Agree & 159 & 40.6 & 40.6 & 100.0 \\
Total & 392 & 100.0 & 100.0 & \\
\hline
\end{tabular}

Table 15. Frequency and percentage distribution of learners' responses on whether many of their family members were successful business owner.

\begin{tabular}{ccccc}
\hline & Frequency & Percent & Valid Percent & $\begin{array}{c}\text { Cumulative } \\
\text { Percent }\end{array}$ \\
\hline Strongly Disagree & 26 & 6.6 & 6.6 & 6.6 \\
Disagree & 113 & 28.8 & 28.8 & 35.5 \\
Neutral & 94 & 24.0 & 24.0 & 59.4 \\
Agree & 95 & 24.2 & 24.2 & 83.7 \\
Strongly Agree & 64 & 16.3 & 16.3 & 100.0 \\
Total & 392 & 100.0 & 100.0 & \\
\hline
\end{tabular}

to being in a paid job. $5.4 \%$ were opposed to this view, while $11.2 \%$ were of either view.

As shown in Table $15 ; 35.5 \%$ of the learners indicated that many of their family members were not successful business owners. $24 \%$ were not able to state the correct position. $40.5 \%$ of learners gave an affirmative response.

Table 16 shows one-sample t-test results for the variable of entrepreneurial ambition of (n) 392 TVET.

The confidence level was set at $95 \%$ or significance of $(p) 0.05$. The population 
Table 16. One-sample t-test on entrepreneurial ambitions of TVET learners.

\begin{tabular}{|c|c|c|c|c|c|c|}
\hline & \multicolumn{6}{|c|}{ Test Value $=3$} \\
\hline & \multirow[t]{2}{*}{$\mathrm{T}$} & \multirow[t]{2}{*}{ df. } & \multirow[t]{2}{*}{$\begin{array}{c}\text { Sig. } \\
(2 \text {-tailed })\end{array}$} & \multirow[t]{2}{*}{$\begin{array}{c}\text { Mean } \\
\text { Difference }\end{array}$} & \multicolumn{2}{|c|}{$\begin{array}{l}\text { 95\% Confidence } \\
\text { Interval of the } \\
\text { Difference }\end{array}$} \\
\hline & & & & & Lower & Upper \\
\hline $\begin{array}{l}\text { a. Intention to start a business upon } \\
\text { graduation. }\end{array}$ & 55.955 & 391 & 0.000 & 2.722 & 2.63 & 2.82 \\
\hline $\begin{array}{l}\text { b. Entrepreneurial aspiration depends } \\
\text { on personality, attitude and ambition. }\end{array}$ & -60.526 & 391 & 0.000 & -1.528 & -1.58 & -1.48 \\
\hline c. Cultural norm to own a business. & 25.407 & 391 & 0.000 & 1.196 & 1.10 & 1.29 \\
\hline $\begin{array}{l}\text { d. At one point in life had considered } \\
\text { starting a business. }\end{array}$ & 29.428 & 391 & 0.000 & 1.237 & 1.15 & 1.32 \\
\hline $\begin{array}{l}\text { e. Hard work and sacrifice important to } \\
\text { succeed as an entrepreneur. }\end{array}$ & -2.363 & 391 & 0.019 & -0.153 & -0.28 & -0.03 \\
\hline $\begin{array}{l}\text { f. Strong passion and desire to become } \\
\text { an entrepreneur. }\end{array}$ & 26.914 & 391 & 0.000 & 1.214 & 1.13 & 1.30 \\
\hline $\begin{array}{l}\text { g. Entrepreneurship a better path to } \\
\text { personal achievement and success. }\end{array}$ & 43.120 & 391 & 0.000 & 1.579 & 1.51 & 1.65 \\
\hline $\begin{array}{l}\text { h. Many family members are successful } \\
\text { business owners. }\end{array}$ & 18.228 & 391 & 0.000 & 0.939 & 0.84 & 1.04 \\
\hline
\end{tabular}

mean and standard deviation were presented in table 4.7. The one-sample t-test was a comparison between males and females that took part in the survey. The degree of freedom ( $\mathrm{df}$ ) is $\mathrm{n}-1$, in this case is 391 . The mean differences between the genders are tabulated in 16 . The significance-sig. ( 2 tailed) for all questions as indicated in the table are less than 0.05 and most of them scoring above the test value of 3 (neutral point on the Likert scale). On average, the responses were above 3; $\mathrm{t}(391)=55.955, \mathrm{p}=0.000$ for intention to start a business; $\mathrm{t}(391)=$ $-60.526, \mathrm{p}=0.000$ for entrepreneurial aspiration; $\mathrm{t}(391)=25.407, \mathrm{p}=0.000$ for cultural norm; $\mathrm{t}(391)=29.428, \mathrm{p}=0.000$ for consideration to starting a business; $\mathrm{t}(391)=-2.363, \mathrm{p}=0.019$ for hard work and sacrifice; $\mathrm{t}(391)=26.914, \mathrm{p}=$ 0.000 for passion and desire to become an entrepreneur; $\mathrm{t}(391)=43.120, \mathrm{p}=$ 0.000 for entrepreneurship as a better path to personal achievement and success; $\mathrm{t}(391)=18.228, \mathrm{p}=0.000$ many family members being successful business owners; This shows that the results are statistically different and significant hence the null hypothesis is rejected.

\subsubsection{One-Way Analysis of Variance for Entrepreneurial Ambitions}

Table 17, containing results of One-Way Analysis of Variance (ANOVA) for entrepreneurship ambitions variable between male and female TVET learners, indicates that the 2-tailed significance level was below the threshold confidence level of 0.05 which is statistically significant for variables (a) to (f) and (h) ranging from 0.062 to 0.472 except for variable $(\mathrm{g})$ at 0.856 which was not significant. This shows that the responses were statistically different for variables (a) to (f) 
Table 17. One-way analysis of variance (ANOVA) comparing male and female TVET learners for entrepreneurial ambitions.

\begin{tabular}{|c|c|c|c|c|c|c|}
\hline & & $\begin{array}{l}\text { Sum of } \\
\text { Squares }\end{array}$ & $\mathrm{df}$ & $\begin{array}{l}\text { Mean } \\
\text { Square }\end{array}$ & $\mathrm{F}$ & Sig. \\
\hline \multirow[t]{3}{*}{$\begin{array}{l}\text { a. Intention to start a business upon } \\
\text { graduation. }\end{array}$} & $\begin{array}{c}\text { Between } \\
\text { groups }\end{array}$ & 0.551 & 1 & 0.551 & 0.634 & 0.426 \\
\hline & $\begin{array}{l}\text { Within } \\
\text { groups }\end{array}$ & 339.324 & 390 & 0.870 & & \\
\hline & Total & 339.875 & 391 & & & \\
\hline \multirow[t]{3}{*}{$\begin{array}{l}\text { b. Entrepreneurial aspiration } \\
\text { depends on personality, attitude } \\
\text { and ambition. }\end{array}$} & $\begin{array}{l}\text { Between } \\
\text { groups }\end{array}$ & 0.382 & 1 & 0.382 & 0.551 & 0.458 \\
\hline & $\begin{array}{l}\text { Within } \\
\text { groups }\end{array}$ & 270.554 & 390 & 0.694 & & \\
\hline & Total & 270.936 & 391 & & & \\
\hline \multirow[t]{3}{*}{ c. Cultural norm to own a business. } & $\begin{array}{l}\text { Between } \\
\text { groups }\end{array}$ & 5.742 & 1 & 5.742 & 3.515 & 0.062 \\
\hline & $\begin{array}{l}\text { Within } \\
\text { groups }\end{array}$ & 637.075 & 390 & 1.634 & & \\
\hline & Total & 642.816 & 391 & & & \\
\hline \multirow[t]{3}{*}{$\begin{array}{l}\text { d. At one point in life had } \\
\text { considered starting a business. }\end{array}$} & $\begin{array}{l}\text { Between } \\
\text { groups }\end{array}$ & 0.414 & 1 & 0.414 & 0.518 & 0.472 \\
\hline & $\begin{array}{l}\text { Within } \\
\text { groups }\end{array}$ & 311.586 & 390 & 0.799 & & \\
\hline & Total & 312.000 & 391 & & & \\
\hline \multirow[t]{3}{*}{$\begin{array}{l}\text { e. Hard work and sacrifice } \\
\text { important to succeed as an } \\
\text { entrepreneur. }\end{array}$} & $\begin{array}{l}\text { Between } \\
\text { groups }\end{array}$ & 1.442 & 1 & 1.442 & 2.756 & 0.098 \\
\hline & $\begin{array}{l}\text { Within } \\
\text { groups }\end{array}$ & 204.106 & 390 & 0.523 & & \\
\hline & Total & 205.548 & 391 & & & \\
\hline \multirow[t]{3}{*}{$\begin{array}{l}\text { f. Strong passion and desire } \\
\text { to become an entrepreneur. }\end{array}$} & $\begin{array}{l}\text { Between } \\
\text { groups }\end{array}$ & 1.166 & 1 & 1.166 & 1.122 & 0.290 \\
\hline & $\begin{array}{l}\text { Within } \\
\text { groups }\end{array}$ & 405.364 & 390 & 1.039 & & \\
\hline & Total & 406.531 & 391 & & & \\
\hline \multirow[t]{3}{*}{$\begin{array}{l}\text { g. Entrepreneurship a better path to } \\
\text { personal achievement and success. }\end{array}$} & $\begin{array}{l}\text { Between } \\
\text { groups }\end{array}$ & 0.025 & 1 & 0.025 & 0.033 & 0.856 \\
\hline & $\begin{array}{l}\text { Within } \\
\text { groups }\end{array}$ & 294.830 & 390 & 0.756 & & \\
\hline & Total & 294.855 & 391 & & & \\
\hline \multirow[t]{3}{*}{$\begin{array}{l}\text { h. Many family members are } \\
\text { successful business owners. }\end{array}$} & $\begin{array}{c}\text { Between } \\
\text { groups }\end{array}$ & 2.500 & 1 & 2.500 & 1.751 & 0.187 \\
\hline & $\begin{array}{l}\text { Within } \\
\text { groups }\end{array}$ & 556.918 & 390 & 1.428 & & \\
\hline & Total & 559.418 & 391 & & & \\
\hline
\end{tabular}


and $(\mathrm{h})$ and not for $(\mathrm{g})$ which had a significance level of more than 0.05 . In spite of these differences in the responses between male and female learners, on average as indicated in the mean scores and mean differences the results are skewed towards upholding the $\mathrm{H}_{1}$ hypothesis, see Table 16 for the mean differences.

\subsubsection{Summary of Findings}

In this section, results of the research findings are presented. The results give answers to research question one. How does a combination of TVET and entrepreneurship education play a role in addressing unemployment, as well as, underutilisation of human resources in order to drive sustainable social economic development in Lusaka province, Zambia?

The findings as displayed in Table 8 show learners opinion whether they intended to start a business when they graduate, revealed that a total of $82.4 \%$ of the learners had intentions of starting a business after graduation, $17.6 \%$ had not made up their mind, while $7.7 \%$ had no intention at all of starting a business. Based on these responses from TVET students the assumption is the introduction of entrepreneurship education in vocational schools is having positive influence on learners, in helping them to consider entrepreneurial activities as alternatives to formal paid employment. If $82.4 \%$ formed successful enterprises after graduation, unemployment can be reduced in the sense that the graduates would be self-employed and their businesses can create employment for others that would work for them.

The findings in Table 9 show learners' opinion as to whether the aspiration to become an entrepreneur depended on personality, attitude and ambition. Many learners at $89.8 \%$ were of the view that the entrepreneurial aspiration depended on the factors of personality, attitude and ambition. $10.2 \%$ were not sure and $6.6 \%$ held a contrary view. This signifies that personality, attitude and ambition are key factors that should be considered when offering entrepreneurship education to TVET learners. Any interventions meant to promote entrepreneurship among vocational students ought to appeal to these three attributes.

The findings displayed in Table 10 for learners' responses on whether in their culture owning a business was the norm. The results were that a total of $44.1 \%$ learners indicated that it was not their cultural norm to own a business, $20.9 \%$ were not sure and only $25 \%$ confirmed that it was a norm in their culture to own a business. It is clear from the responses that in Lusaka province, Zambia owning businesses is not part of the culture. These responses mean that deliberate measures should be taken to teach business ownership culture and to have this virtue entrenched in the local society.

The findings in table of learners' responses on whether at one point in their life had considered starting a business, show that $7.4 \%$ of learners have never thought of starting a business in their life. A total of $88 \%$ indicated of having thought of starting an enterprise, while $4.6 \%$ were of a neutral position. The results show that majority have at one point thought of starting a business, the case then there should have been many businesses that could have been started 
in Lusaka province. This implies that the methods of entrepreneurship education should be devised in such a manner to ensure that those that have thought of starting businesses should actually end up setting up businesses.

The findings in Table 12 on learners' responses as to whether they believed hard work and sacrifice were important in order to succeed as an entrepreneur indicated an overwhelming $93.9 \%$ of learners in affirming that hard work and personal sacrifice were vital attributes for one to be a successful entrepreneur. The disapproval responses stood at $2.8 \%$ and $3.3 \%$ were unsure. The implication is that TVET learners that aspire to become entrepreneurs are getting the understanding that when start their businesses they need to sacrifice and work hard for them to be successful.

The findings in Table 13 on learners' responses as to whether they can do whatever it takes to become an entrepreneur, the results indicated that $74.5 \%$ of the learners expressed passion to become entrepreneurs, 9.4\% were not prepared to strive to be an entrepreneur and $16.1 \%$ were in the middle of the road. The indication is that entrepreneurship education is generating positive attitudes in TVET learners in persuading them to pursue entrepreneurship by the good number of those that they had passion to become entrepreneurs.

The findings in Table 14 of learners' responses on whether they believe becoming an entrepreneur was a better path to personal achievement and success, the results show that a total of $83.5 \%$ learners indicated that becoming an entrepreneur was a better route to personal achievement and success as opposed to being in a paid job. 5.4\% were opposed to this view, while $11.2 \%$ were of either view. Many TVET learners according to the response have come to realize that they can actualize personal achievement through entrepreneurship.

The findings displayed in Table 15 of learners' responses on whether many of their family members were successful business owners, results revealed that $35.5 \%$ of the learners indicated that many of their family members were not successful business owners. $24 \%$ were not able to state the correct position. $40.5 \%$ of learners gave an affirmative response. These responses simply show that there was low business ownership in the families in Lusaka province, hence the small number of local entrepreneurs. Therefore, entrepreneurship education among TVET students is important in order to encourage business ownership.

Overall, the participants' responses to the questions, as analysed through SPSS showed positive responses to acknowledge that a combination of TVET and entrepreneurship education played a vital role in addressing unemployment, as well as, underutilisation of human resources. This was done by analysing the responses that were received from the respondents. Descriptive statistics, one sample t-tests and ANOVA tools in SPSS were used to aid the analysis and interpretation of results. The answers to this question as per the results indicated that unemployment, as well as, underutilisation of human resources can be addressed by the following broad measures: Tapping into the entrepreneurial ambitions of TVET Learners; Encouraging, enticing and appealing to TVET learners to consider entrepreneurship as a vocation or career pathway; Offering en- 
trepreneurship education to TVET learners; Sensitisation and robust rollout of TVET and entrepreneurship education national wide through policy directives; and, Developing appropriate curriculum to support the awareness and recognition that TVET learners are that acquire entrepreneurship knowledge and skills are potential productive human resource for different industry sectors to drive sustainable economic development. The above highlighted broad measures of the findings are further dealt with specifically in detail in the discussions section below.

\section{Discussion}

It is in realisation of the prevailing acute unemployment, as well as, underutilisation of human resources in Lusaka province in Zambia, that it is prudently considered that vocational students should not only be taught technical and vocational skills but there ought to be deliberate action on part of instructors to discover and appeal to the inert entrepreneurial ambitions of learners. Not only is there chronic unemployment, there is abundant human resource in the province that cannot be deployed into productive activities or put to good utilisation owing to lack of vital skills. Most of the youthful population does not have the barest minimum of skills. This scenario has led to waste and sheer underutilisation of human resources. Thus, the call to embark on mass education of the general populace to engage in vocational training, at the same time endeavouring in awakening the passive entrepreneurial spirit of the learners. This is possible as can be evidenced by the remarks made by a senior TVET administrator interviewed at a vocational skills centre in Rufunsa district who said:

We do not train job seekers but we train would be entrepreneurs and business owners.

The administrator was convinced that self-employment was one of the best solutions to tackle unemployment and underutilisation of human resources. The administrator acknowledged that formal paid jobs were in short supply, hence the teaching of entrepreneurship education to TVET learners to enable them set up enterprises. The businesses can then contribute to economic activity by creating employment opportunities and this can lead to economic development in Lusaka province. This conviction is consistent with Preckler (2018) [27] who points out that UNESCO has raised awareness about youth unemployment as one of the most significant problems facing economies and societies in today's world. The assertion is that UNESCO fosters TVET as a solution to youth unemployment, as it can equip youth with the skills required to access the world of work, including skills for self-employment (Preckler, 2018: 69) [27]. The skills for self-employment are not other than entrepreneurial skills, which should be taught right from the start when they enter vocational training schools up to the time when they leave or graduate.

The findings according to results displayed in Tables 7-17 for the means, standard deviations, including t-tests and ANOVA tests, are indicative of the 
positive response from students themselves, who are now aware about the unemployment that exits out there in society. It is from this perspective that is important to tap into the entrepreneurial ambitions of TVET students. There is need to encourage, entice and appeal to TVET students to consider entrepreneurship as a vocation or career pathway. One good example, of awakening students' entrepreneurial ambitions and encouraging them, is that which was cited by a TVET administrator from one of the trades' school in Lusaka district who said:

Most of our students have taken interest in the entrepreneurship subject. Sometimes we invite successful entrepreneurs, to come and give motivational talks to our students. As a result this has caused a lot our students to develop a lot of interest entrepreneurship because a number of them are able to relate and see that they are learning something important capable of making the live better live in future.

The administrator was demonstrating the point that when offering entrepreneurship education it was important that role models, especially, former TVET students that have successfully set up businesses should be invited to come and talk about the achievements and experiences. The idea is to encourage and inspire the learners to follow in their footsteps, and not just teaching from the abstract without them seeing the true living examples or beneficiaries of entrepreneurship educational with a vocational background.

The t-test in Table 16 indicated that many students intended to start businesses when they graduate. At the same time, there was another group of students who had no entrepreneurial ambitions at all, as was disclosed in the following response from a TVET administrator in Lusaka district during an interview:

I have handled basic issues regarding students complain that they don't understand why they should be doing entrepreneurship. They express the dislike for the entrepreneurship because they think that they are learning technical and vocational courses so that after the course, they should go and look for a paid job and that they should not be the ones that have to start businesses to employ other people.

The issue is that some TVET students even after acquiring entrepreneurship education, they will still not venture into entrepreneurship as they are simply comfortable to find a paid job and this can be related to the aspects covered in table 9 which proves that indeed becoming an entrepreneur is also dependent on the key factors of personality, attitude and ambition of the learners.

This confirmed Onweh et al. (2013) [28] assertion that the aspiration to become an entrepreneur depends on personality, attitude and ambition of an individual. Those that seek personal achievement and success were more inclined to express and pursue entrepreneurial ambitions.

The findings in Table 10, also confirmed that it was not a cultural norm for indigenous Zambian families to own businesses, as only $25 \%$ indicated that their 
families were involved in some business activities. This indeed, is an eye opener as it is one of those factors that can help to explain why many businesses are owned by foreign nationals in Zambia. This trend would require deliberate intervention aimed at changing the cultural set up, so that many local people can venture into entrepreneurship and start their own enterprises. The findings also revealed that at one point in a life time, very few people considered starting a business. However, the results indicated that hard work and sacrifice were acknowledged as being important in order to succeed as an entrepreneur. It was clear that a good number of students indicated the desire to become entrepreneurs and they strongly believed becoming an entrepreneur was a better path to personal achievement and success, even though most of their family members were not successful business owners.

Harnessing human resource and providing answers to unemployment that is ravaging majority of the population in Lusaka province, can also be tackled through offering entrepreneurship education to TVET students, as a viable option able to bring about tangible social outcomes, in terms of providing alternative sources of sustainable earnings for communities. Entrepreneurship education is an important influence among students' entrepreneurial intentions in learning institutions (Kuratko, 2005) [23]. Therefore, it is a wakeup call for the trades' schools to ensure that all students take entrepreneurship education, in addition to the vocational subjects. In the past, some TVET training providers were not teaching entrepreneurship as a subject. Document analysis showed that the TVET Authority had decided to issue a directive to all registered TVET institutions in Zambia, through Circular No. TEV/015/2018, dated $10^{\text {th }}$ January 2018, thereby making entrepreneurship a mandatory subject across all the TVET programmes. The Circular read in part stated:

"Entrepreneurship is now integrated in all TEVETA curricula. The entrepreneurship module has since been revised and is examinable."

Furthermore, the findings revealed the following issues: Students indicated that they had benefited much from entrepreneurship lessons offered at vocation colleges and skills centres, and this was confirmed by both results from the administrators' questionnaire and interviews, pointing to the fact that some students had succeeded in starting their own enterprises. Though the effort needed scaling up, because at the moment, the effects and benefits of entrepreneurship education among the population in Lusaka province are still on a small scale. What is required is mass entrepreneurship education and rampant establishment of small enterprises across the whole province to have a Domino effect.

Responses from both students, administrators and government officials on average indicated that the training institutions and learning environments were good and conducive. Of course, there were of number of outliers with very basic infrastructure and which were at the same time not properly maintained. In some districts such districts such as Rufunsa, the nearest vocational skills centre (Chiyota) was more than 120 kilometres away from the Central Business District 
(CBD), making accessibility by the local community extremely difficult. There was a community skills centre within Rufunsa CBD, it was not worth calling a skills centre, because it did not have the proper infrastructure and equipment and was yet registered with TEVETA. One of the researchers visited a private faith based vocational centre at Munpanshya, which was roughly 13 kilometres from the CBD which had 2 students only doing carpentry and joinery. The facility had a well-equipped carpentry workshop but was not being used by the local community, as access was restricted and had not registered with TEVETA. The other place in Rufunsa were skills training was being conducted on a small scale, in limited subjects, was Rufunsa Girls Technical Secondary School under secondary school vocational education and training (SSVET), coordinated by the Ministry General Education, with assessments done by TEVETA. Shibuyunji district does not have a single vocational skills centre and none of the secondary schools in the area has been participating in secondary school vocational education and training, which was not good for the district. Luangwa and Chirundu districts do not have vocational skills centres, apart from the secondary schools in the area taking part in SSVET. This has deprived the local people from the communities around who need skills, as they cannot be allowed to access skills training from the secondary schools which only cater for full time pupils. Kafue district is in a similar dilemma, as the only privately owned skills centre (St. Ambrose) closed down, the nearest vocational centre within the district is Chikupi vocational centre situated about 45 kilometres accessible by a ragged gravel road from the CBD. There was also only one secondary school (Naboye) in Kafue district that was participating in SSVET, the rest are not. Chilanga district has no vocational skills centre that is easily accessible by the community, the nearest was Holy Rosary, a faith based skills centre in Chipapa settlement area and can only take limited numbers with certain gender limitations by virtue of it being a facility that is operated by Catholic nuns. Secondary schools in Chilanga district were also missing out on SSVET as they were not taking part.

The instructors were appropriately qualified, experienced and competent. Most of them had first and second degrees as noted during the interviews and as collaborated by student responses. The trouble was in the application of teaching methodologies, this was attributable to lack of in-serving training, and up skilling opportunities not being availed to some instructors, for them to be up to date with the latest trends and developments. Equally, the administrators were qualified, though some did not demonstrate leadership in the running of institutions. Again, the findings were collaborated from responses from students and senior government officials and the researchers' own observations during the data collection visits. Below is an extract from an interview with a government officer:

We are going into more of capacity building, because this is one area where we have failed. We recruit the instructors and administrator and park them in institutions without giving them opportunities for capacity building. We need to 
build capacity different categories on a continuous basis. If that is done then can do better than we have been doing in the past. The human resource component is one of the weakest parts contributing to the question you asked earlier about the low quality of TVET graduates.

The government officer in charge of TVET admitted that the poor quality of graduates was partly due to lack of capacity building opportunities and support not being offered to TVET instructors and administrators.

The entrepreneurship curriculum was appropriate in terms of relevance, depth and content, however, it was not being revised in time to catch up with technological changes and advancements. This was evidenced by the comment below made by a general manager of large multinational company who was interviewed.

I have been to the technical colleges, and my observation is that students are being training on old technology like carburetor, point's ignition which is now in the museum and they are being tested on that in examinations. As a result from the industry perspective such training is not adding value to industry because there is a big gap on knowledge.

The industry expert illustrated that students were being trained on old technology and old methods which are not relevant to the modern industry. The emphasis was that students should be trained using same or similar equipment, tools and technology that they will find in industry when the graduate to either go and set up their businesses or get employed, otherwise they bound to face difficulties in both instances.

The findings were not impressive when it came to the issues of entrepreneurship learning materials and resources as these were not adequate. Adem (2008) [29] confirmed that entrepreneurship education enables trainees acquire business skills and competencies for identifying business opportunities and run their own businesses. As much as this may be true, the TVET institutions lack entrepreneurship incubation facilities in all the districts in Lusaka province with the exception of a few in Lusaka district. This is a serious challenge, the ideal situation is incubation facilities ought to be available to enable students start their enterprises before graduating. The aspects of start-up capital is critical for would be entrepreneurs, results from this study show that this is a serious problem. The students and administrators' and government responses confirmed that in many instances, learners acquired entrepreneurship skills, but were not able to set up enterprises due to lack of start-up capital. Government officials acknowledged that this was a big challenge and plans were under way to find ways of addressing this problem. The irony is that those that are skilled to run and own businesses, ended up queuing for the unavailable jobs, simply because of the failure to secure capital. This dilemma requires a complete solution, so as not to waste and underutilise human resources trained at great expense. To complicate matters, there was not in a place any start-up capital revolving fund, to which TVET students can go to access finances. When questioned about this challenge one of 
the senior government officials said:

The incubators are there across the country mainly along the main transport corridor in the urban areas. We have a few in rural areas but they are not effective. The government tried the process of incubation in the country in June 2007, with a programme for graduate empowerment, which was an incubation concept and tools worth millions of dollars were being given out to students but the outcome was disastrous. The main reason was because most of our graduates, did not think entrepreneurship teaching was going help them; yes it may help others, but for others, it 's the attitude problem.

The government official was trying to prove the point that not every TVET student can become an entrepreneur and he stated that this had something to do with factor of attitude. He attributed the failure of the incubation initiative undertaken in 2007 to poor attitude amongst the many students that participated. Therefore, the incubation facilities should be made available to learners who have already decided to go into business to avoid wastage of the scare resources made available for incubation.

However, the situation on the ground was that Chilanga, Chongwe, Chirundu, Lunagwa Kafue, Runfunsa and Shibuyunji districts do not have entrepreneurship incubation facilities in the districts and neither are there financing mechanisms to provide startup capital to TVET graduates. Lusaka district in Lusaka province is the only district with incubation facilities at Lusaka business and technical college, though not robust and effective to deal with the scale and size of entrepreneurship education envisaged in this study capable of changing the economic landscape of the province.

\section{Conclusion}

This study aimed to bring about awareness of the prevailing problem of unemployment, as well as, underutilisation of human resources, mainly due to lack of technical, vocational and entrepreneurship skills. The Province has been grappling with high unemployment and gross underutilisation of human resources due to poor skills among the population, lack of entrepreneurship education, and mismatch of qualifications and the availability of jobs. The lack of technical, vocational and entrepreneurship skills was identified as one of the major problems leading to acute unemployment, as well as, underutilisation of human resources. Therefore, this study investigated some of the measures and interventions that government has been implementing, in trying to resolve the problem, by harnessing TVET and entrepreneurship education, in order to drive sustainable social economic development. The key findings aligned with the research objectives and research questions are presented in the below. The research question required collection of data that would give answers, to respond to how a combination of TVET and entrepreneurship education played a role in addressing unemployment, as well as, underutilisation of human resources, in order to drive sustainable economic development in Lusaka province. The results of the 
questionnaire administered to TVET students and interviews conducted with administrators, instructors and parents of TVET learners indicated overwhelming responses showing that TVET students were able to form entrepreneurial ambitions, if introduced to entrepreneurship education during the time they are pursuing their vocational training. Data were analysed using SPSS, specifically, one sample t-tests and one-way Analysis of Variance (ANOVA) were performed. The findings showed that teaching entrepreneurship lessons to vocational students were highly likely to ignite their inert entrepreneurial spirit and ambition. This meant that a good number of students were likely to start their own enterprises in the field of their studies when they exited vocation schools. The results clearly show that self-employment through entrepreneurship in vocational related businesses, is one of the best solutions to address the prevailing acute unemployment and underutilisation of human resources. Furthermore, findings indicated that encouraging TVET students to pursue entrepreneurial ambitions, gives them wider opportunities to access the world of work, as they are equipped with vocational knowledge, skills and competences, in addition to entrepreneurship skills for self-employment in the event they are not able to find paid jobs. The findings showed that ideally, students are being trained to be potential entrepreneurs and not job seekers. Findings indicated that a good number of students intended to start enterprises upon graduation and also some of them had no entrepreneurial ambitions at all.

\section{Conflicts of Interest}

The authors declare no conflicts of interest regarding the publication of this paper.

\section{References}

[1] CSO (2018) Yearly Statistics, Central Statistical Office, Lusaka.

[2] CSO (2015) Living Conditions Monitoring Survey Report. Central Statistical Office, Lusaka.

[3] World Bank (2018) Zambia Overview: Systematic Country Diagnostic. https://www.worldbank.org/en/country/zambia/overview

[4] Trading Economics (2019) Zambia Population. https://www.tradingeconomics.com/

[5] CSO (2012) Zambia's 2010 Census of Population and Housing. Central Statistical Office, Lusaka.

[6] Pillis, E.D. and Reardon, K.K. (2007) The Influence of Personality Traits and Persuasive Messages on Entrepreneurial Intentions: Across Cultural Comparison. Career Development International, 12, 382-396. https://doi.org/10.1108/13620430710756762

[7] Rayan, A. (2015) Technical and Vocational Education and Training for Employment and Sustainable Economic Development through Career Development Program: A Montfortian TVET Experience in the Philippines. International Journal of Research in Humanities and Social Studies, 2, 17-26. 
[8] Grundstén, H. (2004) Entrepreneurial Intentions and the Entrepreneurial Environment: A Study of Technology-Based New Venture Creation. Doctoral Dissertation, Helsinki University of Technology, Espoo, Finland.

[9] Kidane, G.M. and Raju, R.S. (2016) Entrepreneurial Motivation and Determinant Factors of TVET Graduate Students. International Journal of Applied Research, 2, 422-428.

[10] Holland-Noronha, N. (2010) Economic and Socio Cultural Experiences of Female Entrepreneurs in Brazil and the United States: An Exploratorial and Empirical Analysis. Robert Gordon University, Aberdeen.

[11] Suradi, S., Yasin, M.R. and Rasul, M.S. (2017) Increasing Technopreneurs for a Developing a Nation: The Majlis Amanah Rakyat (Mara) Experience. Journal of Technical Education and Training, 9, 73-86.

[12] Hoppers, W.H.M.L. (1984) From School to Work: A Study of Youth: Non-Formal Training and Employment in Lusaka. Institute of Education, University of Utrecht, Netherlands.

[13] Pavlova, M. (2014) TVET as an Important Factor in Country's Economic Development. SpringerPlus, 3, K3. https://doi.org/10.1186/2193-1801-3-S1-K3

[14] Mwiya, B.M.K. (2014) The Impact of Entrepreneurship Education on the Relationships between Institutional and Individual Factors and Entrepreneurial Intention of University Graduates: Evidence from Zambia. Doctoral Dissertation, University of Wolver Hampton, The West Midlands.

[15] Garba, G.A., Onyebuenyi, P.N. and Onoh, B.C.E.C. (2017) Revitalizing Technical, Vocational Education and Training through Entrepreneurship Education for Self Employment in Kogi State. Odumegwu Ojukwu Journal of Vocational Education and Research, 2, 200-208.

[16] Ogbaekirigwe, C.O. and Ugochukwu, C.O. (2017) Relevance of Entrepreneurship in TVET. Technical Education and Vocational Training in Developing Nations. Federal University Ndufu-Alike Ikwo, Nigeria.

[17] Dahalan, D., Lawrence, J., Silva, D., Ismail, I.A. and Mohamed, N.A. (2018) Entrepreneurial Mindset among Students of Technical and Vocational Education and Training (TVET) Institutions in Malaysia. The Journal of Social Sciences Research, 4, 303-311.

[18] WorldFish (2018) Aquaculture Technical, Vocational and Entrepreneurship Training for Improved Private Sector and Smallholder Skills Project in Zambia. Penang, Malaysia: WorldFish. Programme Brief: 2018-12.

[19] Ismail, A., Adnan, W.N., Masek, A., Hassan, R., Hashim, S. and Ismail, M.E. (2019) Effectiveness of Entrepreneurship Programmes in Developing Entrepreneurship Skills towards Quality TVET Graduates. Journal of Technical Education and Training, 11, 81-86. https://doi.org/10.30880/jtet.2019.11.01.010

[20] UNESCO (2015) General Conference-38th Session, United Nations Educational, Paris, 3-18 November 2015.

[21] Bird, B. (1988) Implementing Entrepreneurial Ideas: The Case for Intention. Academy of Management Review, 13, 442-453.

https://doi.org/10.5465/amr.1988.4306970

[22] Lener, M., Brush, C. and Hisrich, R. (1997) Israeli Women Entrepreneurs: An Examination of Factors Affecting Performance. Journal of Business Venturing, 12, 315-339. https://doi.org/10.1016/S0883-9026(96)00061-4

[23] Kuratko, D.F. (2005) The Emergence of Entrepreneurship Education: Development, 
Trends and Challenges. Entrepreneurship Theory and Practice, 29, 577-597. https://doi.org/10.1111/j.1540-6520.2005.00099.x

[24] Kombo, K.D. and Tromp, L.A.D. (2006) Proposal and Thesis Writing: An Introduction. Paulines Publishers, Nairobi, Kenya.

[25] Creswell, J. (2003) Research Design: Qualitative, Quantitative and Mixed Methods Approaches. 2nd Edition, Sage Publications, Thousand Oaks, CA.

[26] Tashakkori, A. and Teddlie, C. (1998) Mixed Methodology: Combining Qualitative and Quantitative Approaches. Sage, Thousand Oaks, CA.

[27] Preckler, M. (2018) Globalization, Mass Education and TVET: The Influence of UNESCO in Botswana and Namibia. Springer, London.

[28] Onweh, V.E., Akpan, N. and Emmanuel, C.E. (2013) Youth Empowerment and the Integration of Entrepreneurship Education into Technical Vocational Education and Training in Nigeria. Academic Journal of Interdisciplinary Studies, 2, 211-216. https://doi.org/10.5901/ajis.2013.v2n2p211

[29] Adem, E.Y. (2008) The Effect of Entrepreneurship Education in TVET Programs as a Source of Motivation for Entrepreneurship. Addis Ababa University, Ethiopia. 


\section{Appendix 1: Questionnaire for TVET Learners (Extract)}

The general objective of this study is to evaluate the effectiveness and success of methods of harnessing technical and vocational education and training, by embracing entrepreneurship education in trying to resolve unemployment, as well as underutilisation of human resources, in order to drive sustainable economic development in Lusaka province, Zambia.

You are kindly requested to be open and honest, as the information you will give, will only be used for the sole purpose of this study. I wish to thank you in anticipation to your positive response.

Name of the TVET Institution:

Location:

District:

Province:

Learner's Year of Study:

Gender: Male Female

PART A. Entrepreneurial ambitions of TVET learners.

\begin{tabular}{|c|c|c|c|c|c|c|}
\hline & & $\begin{array}{l}\text { Strongly } \\
\text { Agree }\end{array}$ & Agree & $\begin{array}{l}\text { Neutral } \\
\text { (Neither } \\
\text { Agree or } \\
\text { Disagree) }\end{array}$ & Disagree & $\begin{array}{l}\text { Strongly } \\
\text { Disagree }\end{array}$ \\
\hline & & 5 & 4 & 3 & 2 & 1 \\
\hline 1 & $\begin{array}{l}\text { You intend to start a business when } \\
\text { you graduate. }\end{array}$ & & & & & \\
\hline 2 & $\begin{array}{l}\text { The aspiration to become an entrepreneur } \\
\text { depends on personality, attitude and } \\
\text { ambition. }\end{array}$ & & & & & \\
\hline 3 & $\begin{array}{l}\text { In your culture owing a business } \\
\text { is the norm (must). }\end{array}$ & & & & & \\
\hline 4 & $\begin{array}{l}\text { You at one point in your life considered } \\
\text { starting a business. }\end{array}$ & & & & & \\
\hline 5 & $\begin{array}{l}\text { Hard work and sacrifice are important in } \\
\text { order to succeed as an entrepreneur. }\end{array}$ & & & & & \\
\hline 6 & $\begin{array}{l}\text { You will do whatever it takes just to } \\
\text { become an entrepreneur. }\end{array}$ & & & & & \\
\hline 7 & $\begin{array}{l}\text { Becoming an entrepreneur is a } \\
\text { better path to personal achievement } \\
\text { and success. }\end{array}$ & & & & & \\
\hline 8 & $\begin{array}{l}\text { Many of your family members are } \\
\text { successful business owners. }\end{array}$ & & & & & \\
\hline
\end{tabular}


PART B. Entrepreneurship education of TVET learners.

\begin{tabular}{|c|c|c|c|c|c|c|}
\hline & & $\begin{array}{l}\text { Strongly } \\
\text { Agree }\end{array}$ & Agree & $\begin{array}{l}\text { Neutral } \\
\text { (Neither } \\
\text { Agree or } \\
\text { Disagree) }\end{array}$ & Disagree & $\begin{array}{l}\text { Strongly } \\
\text { Disagree }\end{array}$ \\
\hline & & 5 & 4 & 3 & 2 & 1 \\
\hline 1 & $\begin{array}{l}\text { You have benefited much from } \\
\text { entrepreneurship lessons. }\end{array}$ & & & & & \\
\hline 2 & $\begin{array}{l}\text { The training institution and learning } \\
\text { environment is good and conducive. }\end{array}$ & & & & & \\
\hline 3 & $\begin{array}{l}\text { The instructors are qualified, experienced } \\
\text { and competent in application of teaching } \\
\text { methodologies. }\end{array}$ & & & & & \\
\hline 4 & $\begin{array}{l}\text { The entrepreneurship curriculum is } \\
\text { appropriate in terms of relevance, } \\
\text { depth and content. }\end{array}$ & & & & & \\
\hline 5 & $\begin{array}{l}\text { Your institution has adequate } \\
\text { entrepreneurship learning materials } \\
\text { and resources. }\end{array}$ & & & & & \\
\hline 6 & $\begin{array}{l}\text { The administrators are qualified and } \\
\text { demonstrate leadership in running the } \\
\text { institution. }\end{array}$ & & & & & \\
\hline 7 & $\begin{array}{l}\text { The institution has entrepreneurship } \\
\text { incubation facilities to enable you to start } \\
\text { your business before you graduate. }\end{array}$ & & & & & \\
\hline 8 & $\begin{array}{l}\text { Start-up capital is critical for } \\
\text { would be entrepreneur. }\end{array}$ & & & & & \\
\hline
\end{tabular}

